\title{
Teknologi bagi Sekolah Dasar di Indonesia
}

\author{
Anita Isa, Rahmelia Diko \\ ${ }^{1}$ Dinas Pendidikan Bone Bolango Gorontalo \\ ${ }^{2}$ Pendidikan Dasar Pascasarjana Universitas Negeri Gorontalo
}

Email: anita.isa@gmail.co.id

\begin{abstract}
ABSTRAK
Penelitian ini bertujuan untuk mendeskripsikan Kurikulum Teknologi Pendidikan Dasar, Pendidikan Teknologi Di Indonesia, Pendidikan Teknologi Di Malaysia, Langkah-langkah Pengembangan Komputer, Dampak Positif dan Negatif Teknologi Pendidikan. Penelitian ini merupakan penelitian deskriptif kualitatif. Teknik pengumpulan data yang digunakan adalah observasi, dan dokumentasi. Hasil penelitian dilakukan mulai dari tanggal 19-22 agustus. Dari hasil dilapangan hasil diskusi. Diperoleh data beberapa keunggulan pendidikan yang ada dari penerapan teknologi. Di Malaysia anak-anak tidak melakukan ulangan-ulangan, belajar untuk ujian pada akhir tingkatan seperti pada saat kelas 6. Malaysia menggunakan sistem pendidikan seperti yang ada pada findlandia. Teknologi sudah banyak di lakukan di sekolah-sekolah dasar, tidak hanya dari kelas atas, tapi sudah mulai dari kelas I. Sekolah-sekolah di Indonesia melaksanakan pendidikan berbasis teknologi dengan menggunakan komputer sebagai media pembelajaran di sekolah. di sisi lain, hal ini mengharuskan sekolah untuk mempunyai sarana prasarana yang mendukung terselenggaranya pembelajaran berbasis teknologi. Bagi sekolah yang tidak mempunyai sarana prasarana yang mendukung maka tidak dapat melaksanakan pendidikan berbasis teknologi
\end{abstract}

Kata Kunci: Kurikulum; Sekolah Dasar; Teknologi

\begin{abstract}
ABSTACK
This study aims to describe the Basic Education Technology Curriculum, Technology Education in Indonesia, Technology Education in Malaysia, Steps in Computer Development, Positive and Negative Impacts of Educational Technology. This research is a qualitative descriptive study. Data collection techniques used are observation, and documentation. The results of the study were carried out starting from August 19-22. From the results in the field the results of the discussion. Data obtained from several educational advantages that exist from the application of technology. In Malaysia, children do not do the repetition, studying for exams at the end of the level as in the 6th grade. Malaysia uses the education system as in Iceland. Technology has been widely applied in primary schools, not only from the upper class, but has started from class I. Schools in Indonesia carry out technology-based education using computers as learning media in schools. on the other hand, this requires schools to have infrastructure that supports the implementation of technologybased learning. For schools that do not have supporting infrastructure, they cannot implement technology-based education
\end{abstract}

Keyword: Curriculum; Primary school; Technology

(C) 2019 Anita Isa, Rahmelia Diko

Under The License CC-BY SA 4.0

PENDAHULUAN

Di era globalisasi, pendidikan mengalami perubahan yang sangat besar. Saat ini, guru menjadi satu-satunya sumber ilmu pengetahuan bagi siswa. Munculnya internet dan media elektronik yang dapat diakses siswa dengan mudah menyebabkan siswa dapat belajar dimana saja dan kapan 
PEDAGOGIKA

Volume 10 (Nomor 1) 2019

Hal. 1-14

saja tanpa harus didampingi oleh guru. Maka, pendidikan juga harus menyesuaikan dengan kecanggihan teknologi yang terjadi saat ini Sebagai salah satu lembaga pendidikan.

Berdasarkan hasil survei yang diadakan oleh The Political and Economic Risk Consultancy, kualitas pendidikan Indonesia di mata dunia internasional sangat rendah. Hal ini ditunjang oleh data yang dikeluarkan oleh indeks sumber daya manusia bahwa pendidikan di Indonesia menempati urutan ke-111 dari 175 negara yang terukur (Hamzah B. Uno dan Nina Lamatenggo, 2011: 92). Maka, kualitas pendidikan harus ditingkatkan sebagai upaya menciptakan Sumber Daya manusia (SDM) yang berkualitas sehingga dapat bersaing di era globalisasi saat ini. Saat ini, peningkatan kualitas pendidikan di Indonesia terus dilakukan dengan berbagai cara. Salah satunya yaitu dengan mengubah pendidikan konvensional menjadi pendidikan berbasis teknologi. Hal ini dilakukan dengan memanfaatkan teknologi informasi dan komunikasi dalam pembelajaran di sekolah. Dengan pemanfaatan teknologi dalam pendidikan maka akan mendukung proses pembelajaran yang menghasilkan siswasiswa yang terampil dalam mengantisipasi kemajuan IPTEK. Sekolah-sekolah di Indonesia melaksanakan pendidikan berbasis teknologi dengan menggunakan komputer sebagai media pembelajaran di sekolah.

Universitas negeri gorontalo memiliki tanggung jawab dalam melahirkan calon pemimpin bangsa yang berkarakter. Oleh karenanya, perkuliahan di dalam kelas saja tidak akan cukup untuk membentuk karakter, dibutuhkan pengalaman dari dunia luar untuk membentuknya agar siap dalam menjalani dunia yang sesungguhnya, terutama dunia kerja. Maka dari itu, Universitas negeri gorontalo mewajibkan seluruh mahasiswanya untuk melaksanakan kegiatan Praktik Kulia Lapangan ke luar negeri untuk dapat melihat langsung bagaimana proses pembelajaran yang ada di sana, aktivitas orang yang berada di sana seperti apa, sehingga bisa mencontoh dan bisa berbagi pengalaman dengan teman dan sekolah yang lain.

Program Kulia Lapangan (PKL) memberikan kesempatan bagi mahasiswa untuk mengimplementasikan ilmu yang telah didapat selama masa perkuliahan ke dunia kerja yang sesungguhnya. Program ini juga berguna untuk melatih mahasiswa untuk beradaptasi dilingkungan baru dan dapat mengetahui kemampuan apa saja yang dibutuhkan di dunia kerja. 
PEDAGOGIKA

Volume 10 (Nomor 1) 2019

Hal. 1-14

Sebagai mahasiswa S2 Pendidikan Dasar program ini sangat bermanfaat karena memberikan pengalaman bagaimana melihat sarana dan prsarana yang digunakan oleh kampus UPSI khususnya pada museum UPSI. Dengan demikian, setelah lulus nantinya para lulusan dari Universitas Negeri gorontalo telah memiliki karakter yang baik dan sesuai harapan masyarakat serta siap berbagi pengalaman di sekolah yang lain.

Terdapat korelasi yang positif antara ilmu pengetahuan dan teknologi. Perkembangan ilmu pengetahuan akan berdampak positif terhadap teknologi yang dihasilkan. Demikian pula sebaliknya, kemajuan teknologi juga berpengaruh besar terhadap perkembangan ilmu pengetahuan, dan juga terhadap perkembangan model konsep kurikulum.

Penerapan teknologi dalam bidang pendidikan khususnya kurikulum adalah dalam dua bentuk, yaitu bentuk perangkat lunak (software) dan perangkat keras (hardware) penarapan teknologi perangkat keras dalam pendidikan dikenal sebagai teknologi alat (tools technologi), sedangkan penerapan teknologi perangjat lunak disebut juga teknologi sistem (system technologi).

Tujuannya diarahkan pada penguasaan kompetensi, yang dirumuskan menjadi hasil belajar siswa. Tujuan yang masih bersifat umum dijabarkan menjadi tujuan-tujuan yang bersifat khusus, yang didalamnya terkandung aspek kognitif, afektif dan psikomotorik.

Metode pengajarannya bersifat individual, dimana setiap siswa mendapat tugasnya masing-masing sesuai dengan kemampuan tingkatbelajarnya. Siswa yang kecepatan belajarnya bagus, sedang maupun lambat mendapat perhatian semua. Tetapi tak menutup kemungkinan para siswa mendapat tugas yang bersifat kelompok untuk mengurangi rasa individual mereka supaya merangsang rasa sosialisasi. Penyampaian materi pada umumnya hanya penegasan kepada para siswa materi yang dipelajari, selanjutnya para siswa belajar mandiri dengan buku-buku dan bahan ajar lainnya.

Bahan ajar atau isi kurikulum diambil dari disiplin ilmu, dengan diramu sedemikian rupa sehingga memudahkan penguasaan suatu kompetensi. Bahan ajar yang besar disusun dari bahan ajar yang kecil sesuai dengan urutannya. Penjabaran seperti ini memudahkan penyampaian materi yang hendak dicapai. Sesuai dengan landasannya, kurikulum teknologi lebih ditekankan pada sifat ilmiah.

Evaluasi dapat dilakukan kapan saja, setelah siswa mendapat topik pelajaran siswa dapat mengajukan diri untuk dievaluasi. Fungsi evaluasi sebagai umpan 
PEDAGOGIKA

Volume 10 (Nomor 1) 2019

Hal. 1-14

balik untuk mengetahui tingkat kemampuan siswa dalam menerima dan memahami topik yang telah disampaikan. Bentuk evaluasi pada umumnya obyektifitas. Seperti halnya model kurikulum yang lain, model kurikulum ini memiliki kelebihan dan kekurangan. Pengajaran yang menggunakan alat-alat yang berhubungan dengan teknologi baru secara umum lebih menyenangkan. Dari sisi pelaksanaanya model pengajaran ini pengusaaan siswa jauh lebih tinggi dibandingkan dengan metode lain. Namun demikian, model pengajaran ini memiliki keterbatasan. Model kurikulum ini kurang bias melayani siswa dengan bakat yang berbeda. Model ini cenderung seragam dengan menggunakan alat yang ada. Keberhasilan siswa tergantung pada teknologi dan juga perasaan mereka terhadap hal tersebut, bila tanggapan siswa positif maka pengusaan materi lebih cepat dan meningkat cepat pula.

Model kurikulum teknologi disesuaikan dengan pemikiran pendidikan. Model ini sangat mengutamakan penguasaan dan pembentukan kompetensi. Model kurikulum teknologi berorientasi pada masa sekarang dan yang akan datang, kurikulum ini juga menekankan pada isi kurikulum. Suatu kompetensi besar dijadikan kompetensi yang lebih kecil sehingga perilaku-perilaku siswa dapat diamati atau diukur.

Jenis teknologi

a. Teknologi cetak

b. Teknologi Audio-video

c. Teknologi berbasis komputer

d. Teknologi terpadu

Teknologi informasi saat ini memang berkembang pesat, kehadirannya begitu masif, nyaris disemua sektor ada. Bukan cuma di kantor, bukan cuma di pusat pemerintahan, bukan cuma di kampus atau lembaga pendidikan, tapi disemua tempat ada. Karenanya wajar kalau para orang tua banyak yang bingung ketika anak-anaknya mulai akrab dengan perangkat teknologi informasi tersebut, maka munculah keingintahuan bagaimana cara mengenalkan IT yang baik kepada anak-anaknya. Agar anak-anaknya bisa mengikuti perkembangan IT, tetapi tidak salah menggunakannya.

Begitupun dengan guru di sekolah dasar, terutama guru yang mengajar mata pelajaran yang berkaitan dengan pemanfaatan teknologi, yaitu guru mata pelajaran komputer. Mereka dituntut bukan cuma harus mengajarkan cara menggunakan perangkat dan aplikasi komputer tapi juga dituntut untuk memberikan pemahaman, atitude, dan etika-etika dalam pemanfaatan perangkat dan aplikasi yang benar sesuai fungsinya kepada anak didiknya. 
PEDAGOGIKA

Volume 10 (Nomor 1) 2019

Hal. 1-14

Seperti banyak para pengamat IT mengatakan bahwa IT itu ibarat pisau, jika benar menggunakannya maka IT itu besar sekali manfaatnya, tetapi jika salah menggunaknnya maka banyak pula mudhoratnya.

Mengenalkan teknologi sejak dini tidak ada salahnya, tapi mengetahui terlebih dahulu manfaat yang akan didapat serta hal buruk yang bisa saja terjadi dari perangkat teknologi yang akan dikenalkan kepada anak merupakan point penting yang harus dipahami para orang tua dan guru.

Misalnya ketika hendak mengenalkan perangkat komputer kepada anak-anak, maka sebaiknya personal yang akan mengenalkan perangkat komputer tersebut harus memahami beberapa hal ini:

1) Dengan menggunakan komputer anak-anak bisa menjadi lebih senang dalam belajar, karena ada aplikasi komputer yang bermanfaat untuk menunjang pembelajaran. Atau minimal anak-anak bisa belajar mewarnai menggunakan aplikasi Paint, mereka akan senang membuat bentuk-bentuk dan warna yang menarik secara digital.

2) Dengan menggunakan komputer juga anak-anak bisa melihat video, mendengarkan musik, dan menggunakan berbagai jenis permainan menarik lainnya yang dapat membuat anak terhibur.

3) Dengan menggunakan komputer yang terhubung dengan internet anak-anak bisa menemukan hal-hal menarik seperti gambar-gambar kartun, video di youtube dan lain sebagainya. Anak-anak juga bisa mendownload berbagai aplikasi dan permainan gratis melalui playstore.

Secara umum komputer bagi anak-anak tak lebih dari perangkat hiburan, mereka akan bereksplorasi dengan berbagai perangkat lunak yang mereka anggap menarik. Karena anak-anak menganggap komputer sepertihalnya perangkat hiburan lainnya, maka hal-hal negatif dekat dengan mereka pada saat menggunakan komputer tersebut.

1) Lupa waktu karena keasyikan mengoperasikan berbagai aplikasi komputer yang mereka anggap menarik seperti games, dan lainnya. Karena lupa waktu itulah anak-anak yang berlama-lama duduk mengoperasikan komputer cenderung menjadi pasif, malas bicara, dan tidak mau untuk bergaul. Ini berbahaya jika dibiarkan, anak akan menjadi pribadi yang individualis dan egois, seolah-olah 
mereka tak butuh orang lain dan asyik dengan dunianya sendiri.

2) Sering bermain Games juga berdampak tidak baik terhadap dunia anak-anak yang seharusnya berlari, loncat, dan melakukan aktivitas anak-anak lainnya. Belum lagi jika games yang dimainkan mengandung unsur kekerasan, dan hal-hal tidak baik lainnya.

3) Begitupun ketika membiarkan anak mengakses internet tanpa pendampingan. Ini sangat berbahaya, karena maraknya konten yang tidak mendidik bisa saja anakanak temukan secara tidak sengaja pada saat melakukan pencarian.

Jika sudah paham hal baik dan hal buruk bagi anak-anak ketika hendak dikenalkan dengan perangkat komputer, maka ketika akan mengenalkan perangkat komputer tersebut para orang tua dan guru akan lebih berhati-hati tentunya. Dibeberapa sekolah dasar swasta sudah banyak yang membuka program pembelajaran komputer, mata pelajaran tersebut biasanya masuk dalam kategori mulok pada struktur kurikulum.

Ada yang memulainya dari kelas tiga, ada yang memulainya dari kelas empat. Tapi ada juga sekolah dasar swasta yang sudah mengajarkan siswanya aplikasi komputer mulai dari kelas satu SD.

Adapun materi pelajaran komputer untuk sekolah dasar, biasanya dimulai dari materi mewarnai dan membuat objek-objek sederhana menggunakan aplikasi Paint, terus naik ke materi yang lebih tinggi sesuai dengan tingkatan kelas. Penyusunan materi biasanya dibuat sendiri oleh guru mapelnya, dengan mempertimbangkan habit sekolah. Kalau sekolah tersebut sekolah berbasis agama, biasanya materi disesuikan dengan materi keagamaan disekolah tersebut. Jadi, sekalipun mengajarkan komputer, tetap saja materi yang dikerjakan siswa adalah materi dari habbit sekolah, ada keselarasan antara penguatan iptek dengan imtak. Nah buat para orang tua yang ingin mengajarkan aplikasi komputer pada anak-anaknya yang masih usia SD, sementara di tempat anaknya sekolah belum ada pembelajaran komputer, para orang tua bisa mengadopsi materi pembelajaran komputer di sekolah dasar yang sudah menyelenggarakan pelajaran komputer tersebut.

Tapi ingat, harus ada keselarasan antara teknologi dengan dunia anak, dan ada keselarasan pula dengan nilai-nilai moralitas dan nilai-nilai keagamaan. Jadi aplikasi yang dipelajari anak jadikan sebagai media belajar, sementara materi nya tetap 
PEDAGOGIKA

Volume 10 (Nomor 1) 2019

Hal. 1-14

mengakomodir kebutuhan pendidikan anak sesuai umurnya..

Sistem pendidikan di Malaysia diatur oleh Kementerian Pendidikan Malaysia (KPM). Pendidikan formal yang ada di malaysia dimulai dari Pra-sekolah, Pendidikan Rendah, Pendidikan Menengah, Pendidikan Pra-Universiti dan Pengajian Tinggi. Pendidikan merupakan tanggungjawab pemerintah federal. Sistem pendidikan nasional meliputi pendidikan prasekolah hingga perguruan tinggi. Pada tahun 2004 pendidikan prasekolah, dasar dan menengah berada dibawah yurisdiksi Kementrian Pendidikan (the Ministry of Education). Sedangkan pendidikan tinggi merupakan tanggungjawab Kementerian Pendidikan Tinggi (the Ministry of Higher Education). Semua bentuk penyelenggaraan pendidikan didasarkan pada visi dan misi. Adapaun visi dan misi utama pemerintahan Malaysia adalah menjadikan negerinya sebagai pusat pendidikan berkualitas dan siap bersaing dangan lembaga pendidikan tinggi di negara lain seperti Singapura dan Australia

Pada dasarnya sekolah di Malaysia dan Indonesia tidak jauh berbeda. Perbedaan yang menonjol dari pendidikan kedua negara tersebut pada nama jenjang kedua negara. Tingkatan jenjang pendidikan juga berbeda contohnya ada pada jenjang sekolah menengah dimana sekolah menengah Malaysia ditempuh dalam jenjang waktu 5 tahun sedangkan di Indonesia 6 tahun.

Negara Malaysia cenderung lebih maju di bidang pendidikan karena kurikulum yang dipakai baku dan tidak sering ada pergantian kurikulum. Berbeda dengan Negara Indonesia yang sering terjadi pergantian kebijakan serta kurikulum sehingga pelaksana teknis di Indonesia lambat untuk berkembang.

Alasan lain yang berpengaruh dalam kemajuan pendidikan di kedua negara adalah bekas dari negara yang berbeda. Hal ini sedikitnya mempengaruhi sistem pendidikan di kedua Negara.

Dilansir Malay Mail, Rabu (30/5/2018), Menteri Pendidikan Malaysia Maszlee Malik menjabarkan sistem pendidikan yang bertumpu pada teknologi dapat membantu meringankan beban para murid dan guru. Tidak hanya teknologi dari segi perangkat keras, Maszlee juga menekankan pentingnya melatih berpikir secara kritis ke para peserta didik Malaysia.

"Kami ingin sistem pendidikan dini lebih terfokus pada konsep mengumpulkan informasi, pemikiran kritis, juga mempelajari cara membawa kemanusiaan pada hal-hal itu," ucapnya. Lebih lanjut, ia mengingatkan pentingnya belajar bahasa asing, dan kemampuan menguasai Bahasa 
PEDAGOGIKA

Volume 10 (Nomor 1) 2019

Hal. 1-14

Inggris sudah tidak bisa dikesampingkan. Pengikutsertaan Bahasa Inggris pada bidang pendidikan diharapkannya dapat mendorong peserta didik dalam merangkul bahasa dan etnis yang berbeda-beda.

Konsep pendidikan yang ditawarkan Maszlee terinspirasi dari sistem di Finlandia, di mana anak usia dini diberikan bekal kepribadian ketimbang banyak mata pelajaran. Sang menteri juga menyebut fokus pendidikan yang demikian sudah sesuai dengan aspirasi dari Perdana Menteri terpilih Mahathir Muhammad. Maszlee Malik sendiri baru saja diangkat menjadi Menteri Pendidikan Malaysia pada Senin (21/5/2018).

Langkah-langkah Pengembangan Pembelajaran Komputer. Kegiatan ini melipiti pengidentifikasian tujuan pembelajaran, kebutuhan belajar atau mengidentufikasi masalah-masalah dalam pembelajaran. Langkah berikutnya adalah melakukan analisis karateristik siswa SD, oleh karena itu program yang akan dikembangkan harus disesuaikan pada usia anak SD. Karateristik siswa yang akan menggunakan dan belajar dari materi yang dikembangkan tidak dapat diabaikan dalam rumusan tujuan. Oleh karena itu, perlu diketahui beberapa karateristik siswa yang relevan dan kondisi dimana program yang dikembangkan akan digunakan. Karateristik siswa tersebut meliputi: tingkatan siswa, apakah program akan digunakan dikelas, bersama materi lain atau digunakan untuk belajar mandiri. Selanjutnya, perlu dipertimbangkan mengenai strategi pembelajaran, khususnya dalam hal ini perlu dipilih jenis media apa yang paling cocok untuk pembelajaran yang dikembangkan. Apakah pembelajaran melalui komputer dianggap paling sesuai dengan kebutuhan? Setelah sampai pada keputusan bahwa pembalajaran melalui komputer adalah yang paling sesuai dengan kebutuhan, maka langkah berikutnya baru dapat dilakukan merencanakan dan menyusun software pembelajaran berbasis komputer. Perencanaan dan penyusunan program pembelajaran berbantuan komputer mungkin dapat dilakukan sendiri tanpa pihak lain. Jika demikian, maka pengembangan software pembelajaran berbasis komputer harus memiliki tiga keterampilan sebagai berikut, pertama; menguasai bidang studi, Kedua; menguasai proses pengembangan media, ketiga; menguasai keterampilan teknis yang diperlukan dalam pemrograman komputer serta menguasai bahasa computer (Riswandi, Hanum, 2013).

$$
\text { Dampak Positif dan Negatif }
$$

Teknologi Informasi dan Komunikasi dalam Pendidikan 
PEDAGOGIKA

Volume 10 (Nomor 1) 2019

Hal. 1-14

1. Informasi yang dibutuhkan untuk menjadi lebih cepat dan lebih mudah dalam mengakses tujuan pendidikan.

2. Inovasi dalam pembelajaran tumbuh di hadapan e-learning inovasi yang lebih memudahkan proses pendidikan.

3. Kemajuan TIK juga akan memungkinkan pengembangan teleconference kelas virtual atau kelas yang berbasis yang tidak memerlukan pendidik dan peserta didik berada dalam satu ruangan.

4. Sistem administrasi pada lembaga pendidikan akan lebih mudah dan lancar karena penerapan sistem TIK.

5. Munculnya media massa, khususnya media elektronik sebagai sumber pengetahuan dan pendidikan pusat.

6. Munculnya metode pembelajaran yang baru, yang memungkinkan siswa dan guru dalam proses pembelajaran. Dengan kemajuan teknologi menciptakan metode baru yang membuat siswa mampu memahami materi yang abstrak, karena materi dapat dibuat dengan bantuan teknologi abstrak.

7. Sistem pembelajaran tidak harus melalui tatap muka. Dengan kemajuan teknologi proses pembelajaran tidak harus mempertemukan siswa dan guru, tetapi juga dapat menggunakan layanan pos, internet dan lain-lain
8. Mengurangi lag dalam penggunaan TIK dalam pendidikan dibandingkan dengan negara-negara berkembang dan negara maju lainnya.

9. Peningkatan kualitas sumber daya manusia melalui pengembangan dan pemanfaatan teknologi informasi dan komunikasi.

10. ICT sebagai sistem pendukung keputusan dalam dunia pendidikan. Guru meningkatkan kompetensi mereka dalam berbagai bidang ilmu pengetahuan dan profil lembaga pendidikan yang diakui oleh Pemerintah.

11. Berbagi hasil penelitian, penelitian yang dipublikasikan dalam internet akan mudah digunakan oleh orang lain di seluruh penjuru dunia dengan cepat. 12.Konsultasi dengan ahli, konsultasi ahli di bidang undangan dapat dilakukan dengan mudah bahkan jika para ahli sangat banyak di tempat.

13. Perpustakaan online, perpustakaan online adalah perpustakaan dalam bentuk digital.

14. Diskusi online. Diskusi online adalah diskusi yang dilakukan melalui internet.

15. Kelas online. Aplikasi kelas online dapat digunakan untuk lembaga-lembaga pendidikan jarak jauh, seperti universitas dan sekolah-sekolah terbuka. "Computer Aided Instruction" telah melihat sedikit 
PEDAGOGIKA

Volume 10 (Nomor 1) 2019

Hal. 1-14

peningkatan kinerja siswa pada pilihan ganda, pengujian standar di beberapa daerah. Computer Aided (atau dibantu) Instruksi (CAI), yang umumnya mengacu pada siswa belajar mandiri atau tutorial pada PC, telah terbukti sedikit meningkatkan nilai tes siswa dalam membaca dan matematika keterampilan atau mata pelajaran lain, meskipun apakah peningkatan ini berkorelasi dengan peningkatan yang signifikan dalam belajar siswa.

16. TIK digunakan dalam mata pelajaran sekolah yang berbeda. Penggunaan ICT untuk simulasi dan pemodelan dalam sains dan matematika telah terbukti efektif, karena memiliki perangkat lunak pengolah kata dan komunikasi (e-mail) dalam pengembangan bahasa dan kemampuan komunikasi siswa.

17. Akses luar sekolah mempengaruhi kepercayaan pengguna. Siswa yang menggunakan komputer di rumah juga menggunakan komputer di sekolah lebih sering dan lebih percaya diri daripada siswa yang tidak memiliki akses di rumah mereka.

Dampak negatif teknologi informasi dan komunikasi dalam pendidikan. Ada biaya besar yang terlibat antara siswa miskin dan pendidikan yang bisa berakhir menjadi kerugian. Hal ini sering disebut sebagai faktor kesenjangan digital. Beberapa dampak negatif dari da
Komunikasi Teknologi Informasi dalam pendidikan, antara lain:

1. Kemajuan TI akan semakin memudahkan pelanggaran Hak Kekayaan Intelektual (HKI) karena akses mudah ke data yang menyebabkan orang plagiatis akan melakukan kecurangan.

2. Meskipun sistem administrasi suatu lembaga pendidikan seperti sistem tanpa celah, tetapi jika ada kecerobohan dalam menjalankan sistem tersebut akan berakibat fatal. Salah satu dampak negatif televisi adalah melatih anak untuk berpikir pendek dan bertahan berkonsentrasi dalam waktu yang singkat (jangka pendek perhatian).

3. Tes Program kerahasiaan semakin terancam tes kecerdasan seperti tes Raven, Differential Uji bakat dapat diakses melalui compact disk. Implikasi dan masalah tes psikologis yang ada akan mudah bocor, dan pengembangan tes psikologi harus berpacu dengan tingkat kebocoran melalui internet.

4. Penyalahgunaan pengetahuan bagi orang-orang tertentu untuk melakukan tindak pidana. Kita tahu bahwa kemajuan di bidang pendidikan juga mencetak generasi e-book tinggi berpengetahuan tetapi moral yang rendah. Misalnya, dengan ilmu komputer yang tinggi maka orang akan mencoba untuk menerobos sistem perbankan dan lain-lain. 
PEDAGOGIKA

Volume 10 (Nomor 1) 2019

Hal. 1-14

5. Tidak membuat TI sebagai media atau sarana hanya dalam belajar, misalnya, kita tidak hanya men-download, tapi masih membeli buku cetak, tidak hanya mengunjungi perpustakaan digital, tetapi juga masih mengunjungi perpustakaan.

6. Pertimbangkan penggunaan TI dalam pendidikan, khususnya bagi anak-anak yang masih berada dalam kendali sementara membuat pembelajaran dengan TI. Analisis pro dan kontra penggunaan.

7. Mahasiswa dan kadang-kadang guru, bisa aspek adiktif teknologi, bukan isi pelajaran. Hanya karena topik dapat diajarkan melalui TI, itu tidak berarti bahwa itu diajarkan secara efektif melalui TI. Bahkan jika subjek dapat diajarkan secara efektif melalui TI, dan ada uang yang tersedia, itu tidak berarti bahwa selalu ada manfaat untuk itu. Ada banyak penelitian atau studi yang dilakukan untuk melihat dan melihat apakah penggunaan TIK dapat meningkatkan pembelajaran.

8. Perlu untuk tujuan yang jelas. TI dipandang kurang efektif (atau tidak efektif) saat tujuan penggunaannya tidak jelas. Seperti untuk menggunakan internet untuk mencari video porno saat menggunakan komputer di sekolah.

Berdasarkan hasil observasi bahwa belum semua sekolah di Indonesia menggunakan lab computer sebagai sarana pembelajaran, hal ini dengan banyak nya sekolah yang berada di sekolah pedalaman, dan jangkauan jaringan sehingga tidak dapat menggunakan atau mengakses melalui computer. Bagi sekolah yang tidak mempunyai sarana prasarana yang mendukung maka tidak dapat melaksanakan pendidikan berbasis teknologi. Hal ini menjadi salah satu penyebab pembelajaran berbasis teknologi belum diterapkan secara optimal di Indonesia. Hasil dari PKL bahwa sekolah rendah yang ada di Malaysia sudah menggunakan computer sebagai media pembelajaran.

\section{METODE PENELITIAN}

Penelitian ini menggunakan penelitian deskriptif kualitatif. Penelitian kualitatif adalah penelitian yang ditujukan untuk mendeskripsikan dan menganalisis fenomena, peristiwa, aktivitas sosial, sikap, kepercayaan, persepsi, pemikiran orang secara individual maupun kelompok. Penelitian deskriptif adalah metode penelitian yang ditujukan untuk menggambarkan fenomena-fenomena yang ada, yang berlangsung saat ini atau saat yang lampau. dilaksanakan pada bulan agustus 2019. Teknik pengumpulan data yang digunakan dalam penelitian ini adalah observasi, dan dokumentasi.

Adapun rincian tahap kegiatan yang praktikan lakukan adalah sebagai berikut: 
PEDAGOGIKA

Volume 10 (Nomor 1) 2019

Hal. 1-14

1. Tahap Persiapan

Pada tahap ini terlebih dahulu mengajukan surat permohonan pada UPSI yang menjadi sasaran tempat untuk melakukan PKL untuk melihat kampus pendidikan tertua yang ada di Malaysia dan bisa dijadikan contoh. Setelah surat diterima bagian admin UPSI dan di setujui serta ini sudah menjadi bagian kerja sama antara UPSI dan PPs UNG. Pada hari selasa senin berangkat dari Indonesia ke Malaysia, kemudian istirahat dan pada besok hari kami melakukan perjalan ke UPSI.

\section{Tahap Pelaksanaan}

Setelah mendapat konfirmasi dari UPSI, pada hari selesa melakukan perjalan ke UPSI, kami di sambut, kemudian melakukan diskusi mengenai kampus, mengenalkan jurusan yang ada, setelah itu melihat rumah adat, alat dapur yang digunakan pada jaman dulu, melihat benda peninggalan pada jaman dulu, sejarah berdirinya UPSI, benda-benda perlengkapan sekolah, mulai dari alat tulis, seragam yang digunakan, selain itu terdapat benda untuk anak-anak yang berkebutuhan khusus. KBRI diskusi tentang perbandingan pendidikan Indonesia dan Malaysia uji komptensi siswa terakhir.

\section{Tahap Pelaporan}

Setelah selesai PKL mulai menyusun laporan pada bulan september dengan mengambil data yang diperlukan selama PKL berlangsung dan ditambah dengan data yang tersedia pada website instansi. Penyusunan laporan dimulai dan selesai pada bulan September.

\section{HASIL PENELITIAN DAN PEMBAHASAN}

Peran teknologi di sekolah dasar sudah banyak di lakukan di sekolah-sekolah dasar, tidak hanya dari kelas atas, tapi sudah mulai dari kelas I. meteri-materi yang diberikan pun disesuaikan dengan usia anak dan mulai dari hal-hal yang terbilang mudah sampai pada hal rumit, dengan menggunakan teknologi ada dampat posotif dan negatif yang di terima oleh anak, itu seua tergantung pada pendampingan orang tua. Ketika mereka belajar di sekolah mereka akan lebih mudah mengakses materi, melihat video langsung tentang pembelajaran, soal-soal dll.

Bila kita berkaca dari Negara tetangga yakni Malaysia bahwa anak-anak usia mudah sudah dikenalkan teknologi, sekolah-sekolah modern bagi anak, sehingga lebih memudahkan anak. Seperti keterangan dari Menteri Pendidikan Malaysia Maszlee Malik menjabarkan sistem pendidikan yang bertumpu pada teknologi dapat membantu meringankan beban para murid dan guru. Tidak hanya teknologi dari segi perangkat keras, Maszlee 
PEDAGOGIKA

Volume 10 (Nomor 1) 2019

Hal. 1-14

juga menekankan pentingnya melatih

beberapa sekolah yang menerapkan

berpikir secara kritis ke para peserta didik pembelajaran berbasis teknologi di Malaysia.

Mengapa pendidikan Malaysia lebih maju, sebab pendidikan tidak menggunakan kebijakan mengubah kurikulum, seperti hal nya di Indonesia. Indonesia sejak pra kemeredekan sampai masa orde baru sudah mengalami banyak perubahan kurikulum dan setiap pemegang kebijakan anak mengubah kurikulum, dan ini semua membuat para guru dan siswa harus mengikuti perubahan itu, sehingga banyak guru yang kesulitna harus menyesuaikan.

(Darmawan, 2012) menyebutkan kendala-kendala yang menyebabkan teknologi belum dapat digunakan seoptimal mungkin, antara lain kurangnya ketersediaan sumber daya manusia, proses transformasi teknologi, dan infrastruktur telekomunikasi. Infrastruktur yang harus ada dalam pembelajaran berbasis teknologi yaitu komputer, jaringan internet, LCD proyektor, dan sarana yang mendukung lainnya. Selain itu, komponen sumber daya manusia yang mendukung yaitu adanya guru yang mempunyai kemampuan dalam menguasai dan memanfaatkan komputer. Hal tersebut merupakan komponen penting yang mendukung dalam implementasi pembelajaran berbasis teknologi. Kendalakendala ini lah yang menyebabkan hanya Indonesia, khususnya pada jenjang Sekolah Dasar (SD).

Bila kita melihat pendidikan di Malaysia pada jenjang sekolah rendah atau di Indonesia sekolah dasar, di Malaysia siswa tidak melakukan ulangan-ulangan seperti yang ada di Indonesia, Indonesia ulangan yang harus tempu oleh siswa mulai dari ulangan harian-pada ulangan UAS atau kenaikan kelas, sedangkan di Malaysia mereka melakukan ujian hanya pada tingkat akhir atau yang di sebut ulangan akhir kelulusan siswa kelas 6.

Pendidikan di Malaysia seperti yang di informasikn oleh menteri pendidikan terinspirasi dari Finlandia. Dimana finlandia tidak membebani siswa dengan tugas sekolah, siswa tidak di berikan PR apalagi ulangan-ulangan.

Sekolah-sekolah di Indonesia melaksanakan pendidikan berbasis teknologi dengan menggunakan komputer sebagai media pembelajaran di sekolah. Namun di sisi lain, hal ini mengharuskan sekolah untuk mempunyai sarana prasarana yang mendukung terselenggaranya pembelajaran berbasis teknologi. Bagi sekolah yang tidak mempunyai sarana prasarana yang mendukung maka tidak dapat melaksanakan pendidikan berbasis 
PEDAGOGIKA

Volume 10 (Nomor 1) 2019

Hal. 1-14

teknologi. Hal ini menjadi salah satu penyebab pembelajaran berbasis teknologi belum diterapkan secara optimal di Indonesia. (Riswandi, Hanum 2013 hal 95).

\section{KESIMPULAN}

Sebagai mahasiswa S2 Pendidikan Dasar program ini sangat bermanfaat karena memberikan pengalaman bagaimana melihat sarana dan prsarana yang digunakan oleh kampus UPSI khususnya pada museum UPSI. Mahasiswa melaksanakan Praktik Kulia Lapangan di Universitas Pendidikan Sultan Idris Khususnya pada museum UPSI. Waktu pelaksanaan Praktik Kulia Lapangan adalah kurang lebih selama 4 Hari terhitung sejak tanggal 19-22 agustus 2019. Selepas 89 tahun melalui pelbagai perkembangan dan pembangunan pendidikan, Bangunan Suluh Budiman sewajar dijadikan Muzium Pendidikan nasional kerana bangunan tersebut merupakan ikon utama kepada UPSI yang telah ramai melahirkan tokoh pendidikan negara seperti Zainal Abidin Ahmad (Za'aba), Harun Aminurrashid dan Abdul Rahman Talib. Kedutaan besar Republik Indonesia (sering disingkat sebagai KBRI) adalah kantor perwakilan utama Indonesia di sebuah negara asing yang memiliki hubungan diplomatik dengan Indonesia dan dikepalai oleh seorang duta besar. Pendidikan di Malaysia seperti yang di informasikn oleh menteri pendidikan terinspirasi dari Finlandia. di Malaysia siswa tidak melakukan ulangan-ulangan seperti yang ada di Indonesia, Indonesia ulangan yang harus tempu oleh siswa mulai dari ulangan harian-pada ulangan UAS atau kenaikan kelas, sedangkan di Malaysia mereka melakukan ujian hanya pada tingkat akhir atau yang di sebut ulangan akhir kelulusan siswa kelas 6 .

\section{REFERENSI}

Armansyah Putra. Mengkaji \& Membandingkan Kurikulum 7 Negara (Malaysia, Singapura, Cina, Korea, Jepang, Amerika dFinlandia). Perbandingan Kurikulum 2017. Jurnal. Hal 8-10.

Darmawan, D. (2012). Teknologi Pembelajaran. Bandung: PT Remaja Rosdakarya.

Hamzah B. Uno dan Nina Lamatenggo. (2011). Teknologi Komunikasi dan Informasi Pembelajaran. Jakarta: Bumi Aksara.

http://shahir.blogspot.com/2011/07/muzium -pendidikan-nasional.html.

https://id.wikipedia.org/wiki/Kedutaan_besa r_Republik_Indonesia.

https://www.liputan6.com/tekno/read/35347 05/sistem-pendidikan-malaysia-bakallebih-fokus-ke-teknologi.

Riswandi, B.A., Hanum, F.F. 2013. Inovasi dan Kewirausahaan. 2013 Peningkatan Kualitas Siswa Terampil Iptek Dengan Edukasi Komputer Bagi Siswa Sd Di Dusun Wonolelo. Jurnal. Volume 2. Halaman 95-97.

Rita Eka Izzaty. (2008). Perkembangan Peserta Didik. Yogyakarta: UNY Press 


\section{PEDAGOGIKA}

Volume 10 (Nomor 1) 2019

Hal. 1-14 